sheet heated for various times at $180^{\circ}$ and $225^{\circ}$. The crystal structure, as observed by electron diffraction (work carried out in the Metallurgy Division, National Physical Laboratory), has been compared with the composition of the film as determined by chemical analysis, the relative thickness being assessed from the total iron content of the film.

The films have been stripped by the alcoholic iodine $\operatorname{method}^{2}$, using specimens previously dipped in 'Formvar' (polyvinyl formal) resin. The oxide film is removed together with the thin resin backing and the reinforced film transferred to a wire grid for examination in the electron diffraction camera. For chemical analysis the films are dissolved in acid and the solution examined for ferrous and ferric iron.

The electron diffraction work was carried out on a Finch camera with the usual type of cold-cathode electron source and saturated diode stabilization. The films were examined both in situ on the metal surface by the reflexion method and by the transmission technique after stripping. At least two separate areas of each specimen were examined.

Confirming earlier work, there was no progression of interference colours at $180^{\circ}$, but at $225^{\circ}$ the usual sequence of bright colours was observed.

Electron diffraction (reflexion and transmission) patterns showed that the films, both at $180^{\circ}$ and $225^{\circ}$, consist of an outer layer of rhombohedral $\alpha-\mathrm{Fe}_{2} \mathrm{O}_{3}$ overlying cubic oxide of composition between $\gamma-\mathrm{Fe}_{2} \mathrm{O}_{3}$ and $\mathrm{Fe}_{3} \mathrm{O}_{4}$. It follows, therefore, that the phenomenon in question cannot be associated with any major crystalline change in the film at the critical temperature. On the other hand, preliminary chemical analyses have yielded the remarkable result that, for films produced at $180^{\circ}$, the values of ferric and total iron are approximately constant over the range 20-453 hours of heating. It follows that over this range there is virtually no increase in the thickness of the film removed by stripping. On the reasonable assumption (for which previous work ${ }^{2}$ provides evidence) that it is on this film that the development of interference colours depends, a simple explanation is forthcoming why such colours do not, in fact, develop. It remains, however, to explain why thickening of the film is suspended, notwithstanding that oxygen uptake continues, with progress. ive increase in the weight of the specimen.

At $225^{\circ}$, for all periods of heating, uptake of oxygen contributes directly to the thickening of the film, as shown by its total oxygen content. At the lower temperature, oxygen uptake in excess of that required to produce the strippable film must add to the content of iron oxide beneath the film, that is, in the immediately underlying 'mixed zone'. ("iron oxide incorporated sporadically in a matrix of iron"2) or "zone of interlocking"3. Clearly, however, this can occur only by the diffusion of oxygen inwards through the surface film (in accordance with the views of Valensis), in contradistinction to the accepted Wagner mechanism at the higher temperatures in which metal ions diffuse outwards through a defective lattice of the oxide.

The mode and rate of growth of the film must depend upon the relative rates of diffusion of (i) oxygen (whether as ions, atoms or molecules) through the outer rhombohedral zone, and of (ii) iron ions through the inner cubic zone. It is unlikely that the temperature coefficient will be the same for each of these processes. The evidence suggests that the curve for (ii) is steeper than that for (i) and that the two curves intersect at c. $200^{\circ}$. Thus, below $200^{\circ}$ oxidation is propagated mainly by diffusion of oxygen inwards, above $200^{\circ}$ by diffusion of iron outwards; on this view, the difference in the slopes of the respective (diffusion) temperature-coefficient curves accounts for the inflexion in the (oxidation-rate) temperaturecoefficient curve that is experimentally observed at $200^{\circ}$. It is inherent in this argument that the relative diffusion rates will depend very appreciably upon the initial surface condition of the metal. Thus, the value of c. $200^{\circ}$ is characteristic of polycrystalline surfaces prepared by careful abrasion (not 'polishing'). As mentioned in Dr. Evans's contribution, lower critical values have been reported for single crystals and for surfaces produced by polishing.

Furthermore, the diffusion of iron ions outwards through the lattice of the oxide film $\left(>200^{\circ}\right)$ must produce new oxide on the outer interface ; there is no reason to suppose that this could result in anything but a simple thickening of the film. The position is quite different with the reverse process $\left(<200^{\circ}\right)$, since oxygen atoms arriving at the metal/film interface encounter a mixed assembly of metal matrix and (magnetic) oxide nuclei. It can readily be understood that oxidation will now proceed by the growth of pre-existing nuclei rather than by simple film-thickening. This conclusion is in substantial agreement with that reached, as the result of an entirely different mode of approach, by Dr. Evans in his accompanying contribution.

It remains to add that the 'veil' of magnetite described by Dr. Evans as clinging to his separated film is, in the Teddington film-stripping technique, left as a residue on the metal substrate when the film is removed. The distinction arises necessarily from the different experimental characteristics of the two methods. In each case, however, the material must incorporate the magnetic oxide 'nuclei' referred to in the two communications.

The foregoing is a preliminary account of work still in progress, the results from which will be published in greater detail elsewhere. We wish to express our indebtedness to Dr. F. Wormwell for helpful discussion.
W. H. J. VERNON
T. J. NuRse
Chemical Research
Laboratory,
Teddington, Middlesex.

$$
\begin{aligned}
& \text { C. J. B. Cuews } \\
& \text { E. A. CALNAN } \\
& \text { National Physical } \\
& \text { Laboratory, }
\end{aligned}
$$
${ }^{1}$ Vernon, W. H. J., Trans. Farad. Soc., 81, 1670 (1935).

'Vernon, W. H. J., Wormwell, F., and Nurse, T. J., J. Chem. Soc.. 621 (1939).

${ }^{3}$ Evans, U. R., and Stockdale, J., J. Chem. Soc., 2651 (1929).

- Valensi, G., Métaux et Corrosion, 12, 195 (1937).

\section{SCIENTIFIC RESEARCH IN THE RHODESIAS AND NYASALAND}
A REPGfyeto the Central African Council on A the Rlgional Organisation of Research in the Rhodes as and Nyasaland*, by Dr. J. E. Keyston, ho relinquishing his present position as research dechetary under the Council towards the end of the tear, has been considered by the Central African Council and by the three Governments. Although Dr. Keyston's main recommendation that a joint research council should be established has not been adopted, a Standing Advisory Committee for Research
* Central African Council. A Report on Regional Organisation of Research in the Rhodesias and Nyasaland. By Dr. J. E. Keyston. Pp. iv +91 . (Salisbury: Central African Council, 1949.) ${ }_{58}$. 
is to be appointed to devise means of mutual assistance between the territories in research activities, to advise on the priority of research needs and to prevent overlapping of effort. The work of this Committee will be much simplified by the report which Dr. Keyston has prepared.

Dr. Keyston's report is in three parts. The first consists of the survey of the present provision for scientific research in the Rhodesias and Nyasaland which, on account of the many deficiencies revealed, leads him to conclude that the essential element in effecting collaboration in research is a joint research council. Not only is there far too little research, and especially applied research, but also central organisation of research is lacking, and the support and control of research are too exclusively in the hands of Government. Co-operation between Government departments, commerce and industry is inadequate, there is waste of expenditure and staff and lack of long-term planning; there are no centralized services such as a scientific and technical information bureau and specialist library. Dr. Keyston also regards the conditions of service affecting research workers as unsatisfactory and the arrangements for guaranteeing the supply of scientific man-power as inadequate; nor is there sufficient co-operation in research with other countries. He discusses in some detail the problem of keeping research staff fresh in outlook, receptive of new ideas and techniques, self and mutually critical, and creative; and he stresses the contribution to this end which co-operation between the three territories, permitting the interchange and intermingling of staff, could make. He envisages in particular an arrangement between the three Governments and that of the United Kingdom to enable scientific workers in the Colonial Service, the Colonial Research Service or that of Southern Rhodesia to be seconded for service in any of the three Central African territories without loss of rights and benefits, and the appointment of staff on a joint RhodesiaNyasaland basis under the suggested research council.

The second part of the report outlines a suitable constitution for the proposed Rhodesia-Nyasaland Research Council, to which Dr. Keyston appends some notes on such a council as a corporate body; on co-operation between it and the Colonial Office on the choice of site for its headquarters, which he suggests should be at Salisbury; on the effect of pension provisions on the relative mobility of scientific men in the United Kingdom Government Scientific Civil Service and the Southern Rhodesia Government Service, in which the great advantages of the United Kingdom pension system are indicated; on the general pattern of Commonwealth scientific liaison; and on a Central African scientific library and a scientific information bureau for Government agencies in the Rhodesias and Nyasaland. The establishment of scientific information and liaison services would be one of the first tasks of the research council, others being the long-term planning of research and research facilities, the arrangement of partnerships between Government and industry (including agriculture) in the conduct and support of research, stimulation of the interest of local youth for training for research careers, negotiation of contracts for research assistance from organisations in other countries and encouragement and solicitation of research bequests and grants from private philanthropic sources.

The major part of the report is a survey of the most important research requirements of the
Rhodesias and Nyasaland in which joint action can be recommended. In this Dr. Keyston reviews the different fields of science to illustrate the way in which co-operation in meeting these needs might be furthered by a Rhodesia-Nyasaland research council. In geodetic and topographical surveys, however, he points out that the present need is for separate action by Northern Rhodesia and Nyasaland to augment the efforts of the Colonial Geodetic and Topographical Survey. In regard to geological research, he recommends the establishment within the Department of Geological Survey at Salisbury of a Central African geophysical research station with at least five research officers, preferably as a research unit of the proposed research council, and close liaison and collaboration with the Geological Survey of the Union of South Africa is also recommended. The three territories already enjoy a joint meteorological service provided by the Southern Rhodesia Department of Meteorology; but Dr. Keyston directs attention to the desirability of establishing in Salisbury a Southern African meteorological research centre supported by contributions from all Southern African territories, and also urges the extension of the activities of the Salisbury Department of Meteorology in the collection of climatological data of interest in agricultural research and development. There is a need for a central group of hydrological experts to plan a more systematic collection of the water records now being taken, to investigate the broad scientific relations between water-level, water-flow, geological features, soil characteristics and meteorological conditions; and to promote research into such matters as the extent to which underground water supplies are being used up or replenished, the effects of forests, pastures, cultivation and various crops on evaporation, run-off and seepage, and the basic trends and causes of longperiod variations in the levels of lakes and the area of marshes and swamps. He strongly urges the establishment of a Central African hydrological research group with at least six research officers.

In regard to agricultural research, the problem of organisation is how to recruit and deploy most rapidly sufficient research workers of high quality under able and flexible direction in conformity with a soundly planned strategy. He strongly advocates the establishment of a Central African ecological research unit under the proposed research council, and the council should also seek to foster the increased economy and efficiency which would result from joint use of the services of commodity experts by agricultural departments, as well as arrange co-operation in commodity research with external territories and establish research on a research association basis for the cultivation of any commodity which, like tobacco in Southern Rhodesia, assumes the magnitude of a major industry. Tea research in Nyasaland he would organise under a tea research association. Pasture and farming system experimental stations are required in every distinct vegetation-soil sub-division of agricultural importance in the territories. The one central research centre staffed to investigate funds. mental pastoral problems required to serve Southern Rhodesian needs could simultaneously meet similar needs for Northern Rhodesia and Nyasaland. When given such Central African status and responsibility the Southern Rhodesian Grassland Research Centre should remain an integral part of the Department of Agriculture, Salisbury, while the agricultura research committee of the proposed research counci would be made advisory to the Secretary of Agri 
culture, Salisbury, for the broad programme of joint grassland research.

Dr. Keyston deals in some detail with the organisation of tobacco research under the suggested Rhodesia Nyasaland tobacco research association. $\mathrm{He}$ advocates also the establishment on a Central African footing of an agricultural machinery experimental station which might possibly also serve South and East Africa. Stress is laid on the importance of soil science; for a Central African soil laboratory the Agricultural Chemical Laboratory of the Department of Agriculture, Southern Rhodesia, provides the obvious nucleus. One central laboratory is required with good facilities for plant breeding, pathological and physiological research, including some accommodation for fundamental plant research, and specifically in association with the new herbarium to be constructed at Salisbury there should be provided good laboratory and nursery facilities for plant genetical, pathological and physiological investigations, including accommodation for visiting research workers. The same herbarium should be planned and constructed as a Central African herbarium, offering to all those territories scientific facilities and amenities comparable with those which the Royal Botanic Gardens at Kew offer to the United Kingdom. Forestry research is of especial importance. While substantially all sylvicultural research should be organised within the forestry departments of the three territories, most research on the utilization of timber is regarded as appropriate for a Central African construction experiment institute. Establishment on the copper belt of a chemical research laboratory to undertake work on wood chemistry, the discovery of new products derived from natural vegetation, agricultural crops and wastes and industrial chemical research pertinent to the establishment of Central African industries is suggested. Entomological research should be supervised by a Central African entomological research committee of the council, and in particular a Central African tsetse survey team, visualized as a self. contained mobile unit, is recommended.

For veterinary research in Southern and Northern Rhodesia, it is suggested that the veterinary departments at Salisbury and Mazabuka should each establish a research unit of not less than four officers, and that satisfactory arrangements should also be made with the Department of Agriculture, Pretoria, and the East African Veterinary Research Organisation, to include Rhodesian interests; but there is as yet no need for participation by Nyasaland in joint arrangements. Dr. Keyston strongly recommends that Southern Rhodesia should base its organisation for fisheries investigation on participation in the fisheries research project already prepared by the Northern Rhodesia and Nyasaland Governments. He suggests that the research council should stimulate more research on the fauna of Central Africa and that a fauna research committee should be set up, though the recruitment of biologists for such research is not recommended. Strongly supporting the conclusions relating to medical research in Southern Rhodesia of the report of the National Health Service Inquiry Commission (1946), Dr. Keyston recommends the institution, under the proposed RhodesiaNyasaland research council, of a medical research committee and a Central African medical research staff under an experienced specialist as director with headquarters, including specialist library, at Salis. bury. The maximum co-operation should be fostered between research and public health organisations. and arrangements made for interchange of staif annually between medical research authorities in the United Kingdom and the Union of South Africa and the new research centre. The programme of medical research should include disease surveys and nutritional surveys, while bilharziasis and malaria require special attention.

Sociological research directed towards assisting the administration is imperatively needed, and Dr. Keyston recommends the establishment of a Central African sociological research centre at Salisbury, whether or not this can be formed by re-siting and re-organising the Rhodes Livingstone Institute; and the programme of research should also comprise social experiment and fundamental sociological and anthropological studies. Besides all this, the report stresses the need for African personnel research, for which purpose a special research committee should be formed under the council, and the council should also be provided with statistical officers and with an operational research unit of at least six officers. To deal with buildings, roads and civil engineering works, a civil engineering research committee of the council is desirable as well as a co-ordinating committee for archæological and historical research and a museums board. On a rough estimate, Dr. Keyston puts the initial capital expenditure on the programme detailed in this third part of the report at $£ 135,850$, and the recurrent annual expenditure at $£ 266,000$; and a table is appended indicating the distribution of the expenditure between the different activities and the three Governments concerned. Scientific workers will note with appreciation the attention given throughout the report to conditions of service, which are clearly designed to prevent either staleness or the sense of isolation so detrimental to creative work.

\section{UNIVERSITY AND RESEARCH SECTION OF THE LIBRARY ASSOCIATION}
ANNUAL MEETING
$\mathrm{T}$ HE Uni ersity and Research Section of the Libran Association held its annual conference at Carlyle Hostel, Edinburgh, during September 15- 19. It was the first time that the Section had met in Scotland, and members took full advantage of the opportunity of visiting the many fine libraries and scholarly institutions in Edinburgh. The Section was welcomed by the principal of the University of Edinburgh, Sir Edward Appleton, at a reception in the Upper Library of the University. Sir Edward referred in his address to the spate of scientific literature confronting the research worker, and also urged the setting up of some central body to maintain a register of translations of papers originally written in unfamiliar languages.
Mr. R. Irwin, director of the University of London School of Librarianship, opened a discussion on training for university and research librarianship. He stressed the fact that the School course is a post- graduate course entirely, and urged university librarians to rely on the School for some, at least, of their trained recruits for permanent posts on library staffa. Mr. Irwin suggested that a starting salary of at least $£ 350-£ 400$ should be offered to the trained 